\title{
Comparative life cycle assessment (LCA) of pork using different protein sources in pig feed
}

\author{
K. Reckmann ${ }^{1}$, R. Blank ${ }^{2}$, I. Traulsen ${ }^{1}$, and J. Krieter ${ }^{1}$ \\ ${ }^{1}$ Institute of Animal Breeding and Husbandry, Christian Albrechts University, \\ Olshausenstraße 40, 24098 Kiel, Germany \\ ${ }^{2}$ Institute of Animal Nutrition and Physiology, Christian Albrechts University, \\ Olshausenstraße 40, 24098 Kiel, Germany \\ Correspondence to: K. Reckmann (kreckmann@tierzucht.uni-kiel.de)
}

Received: 8 May 2015 - Revised: 27 October 2015 - Accepted: 19 November 2015 - Published: 21 January 2016

\begin{abstract}
Feed production is the main contributor to a subset of environmental impacts of pork production. In this context, this study is concerned with the substitution of soy products in pig diets in order to reduce these impacts. The aim of this study was to assess three alternative diets in gestating and lactating sows as well as growing and finishing pigs in order to reduce the amount of soy products used as ingredients. In the three alternative scenarios soy proteins were compensated for by either using a combination of different feedstuffs (e.g. rapeseed meal, fava beans, and synthetic amino acids) (LOW), maximising the use of legumes (mainly fava beans) (LEG) and increasing the amount of synthetic amino acids (AA). These alternative scenarios were compared with standard diets (ST) and formulated in order to reduce the crude-protein content of the diet while maintaining the same performance of the pigs. Each of the resulting 16 diets was then assessed with respect to global warming, eutrophication, acidification, and land use, both when accounting and not accounting for emissions due to land use change. The analysis per kilogram of feed showed that the ST diets performed best with regard to global warming, eutrophication, and acidification. When emissions from land use and land use change were added, ST and AA diets appeared to have the least impact. In contrast, the assessment of scenarios per kilogram of pork highlighted that the AA scenario contributed the least in all impact categories. In conclusion, it is possible to partly replace soybean products by using synthetic amino acids in order to minimise the environmental impacts of the pork supply chain.
\end{abstract}

\section{Introduction}

Feed production has contributed to the environmental impacts of pork production in Europe (Basset-Mens and van der Werf, 2005; Dalgaard et al., 2007; Nguyen et al., 2011; Reckmann et al., 2013), causing the majority of emissions. Thus, it is important to improve the feeding stage in order to reduce environmental emissions from the production of pork (van der Werf et al., 2005). Despite several mitigation strategies suggested in different studies (Cederberg et al., 2005; de Boer et al., 2011; Nemecek et al., 2008), the substitution of soybean products in animal feed seems to have the greatest potential for minimising the environmental impact (Hörtenhuber et al., 2011; Lehuger et al., 2009; Eriksson et al., 2005; van der Werf et al., 2005; Weightman et al., 2011). A large share of greenhouse gas emissions from using soybean products is related to crop production, transport, and land use change (LUC) (Meul et al., 2012). LUC refers to the conversion of land used, for example the transformation of land from forest or pasture land into agricultural land for the cultivation of crops used as ingredients in livestock feed manufacturing. Land is a limited resource already being put under great pressure (Flysjö et al., 2012), whereas the global livestock sector occupies $75 \%$ of the world's agricultural land (Foley et al., 2011). One third of this proportion is used for crop production intended for livestock feed production. The cultivation of soybeans for livestock feed manufacturing has expanded rapidly in recent years so that taking emissions 
from LUC into account is important. Therefore, improving feed production in the livestock supply chain has a great potential to minimise impacts related to LUC. Recent studies indicated that LUC contributes $9 \%$ of total anthropogenic $\mathrm{CO}_{2}$ emissions (Peters et al., 2012), indicating the dire need to reduce the emissions. Generally, emissions from LUC are divided into emissions related to direct LUC (dLUC) and indirect LUC (iLUC). Alternatively, it is assumed that any occupation of land is responsible for deforestation, independently of where in the world it takes place, resulting in iLUC (Audsley et al., 2009; Schmidt et al., 2011). However, it is difficult to account for emissions related to LUC because there is no consensus on how to address these emissions. Flysjö (2012) and Meul et al. (2012) criticised the difficulties of choosing a method and highlighted that several studies investigating the environmental effects of substituting soybean products in pig feed did not come up with a consistent conclusion in terms of diet formulation. Accordingly, variations in environmental assessments of alternative diets have been observed among different studies, mainly due to the methodological choices for the inclusion of LUC emissions being incompatible.

The aim of this study was to assess the environmental implications of reduced soy products used in the diets of farrowing and fattening pigs. Thus, a life cycle assessment (LCA) of alternative scenarios of reduced soy content in the diets of sows and fattening pigs was performed, focusing on providing feed recommendations for commercial farm conditions. Hitherto, all studies dealing with an LCA of pig feed set their system boundary at the gate of the feed company. In order to come up with comprehensive conclusions considering the whole pork supply chain, the present study additionally accounted for downstream processes as for as the gate of the slaughterhouse, to identify processes (e.g. manure composition) which might be influenced by the different pig diets.

\section{Materials and methods}

An LCA of pig diets was conducted, using four different diet compositions each in the farrowing and fattening stages. Results were calculated both per kilogram of feed and per kilogram of pork applying three different LUC accounting methods: LUC not included; dLUC emissions included; total direct and indirect LUC emissions included. A schematic overview of the considered systems within the system boundaries chosen is illustrated in Fig. 1.

\subsection{Pig diets}

Environmental impact assessments of standard diets (ST) for gestating and lactating sows (GE and LA, respectively) as well as for growing (GRO) (30-70 kg) and finishing (FI) (70$120 \mathrm{~kg}$ ) pigs were performed using an attributional LCA approach, which aims at understanding the magnitude of different life cycle stages. Details on the methodology and its

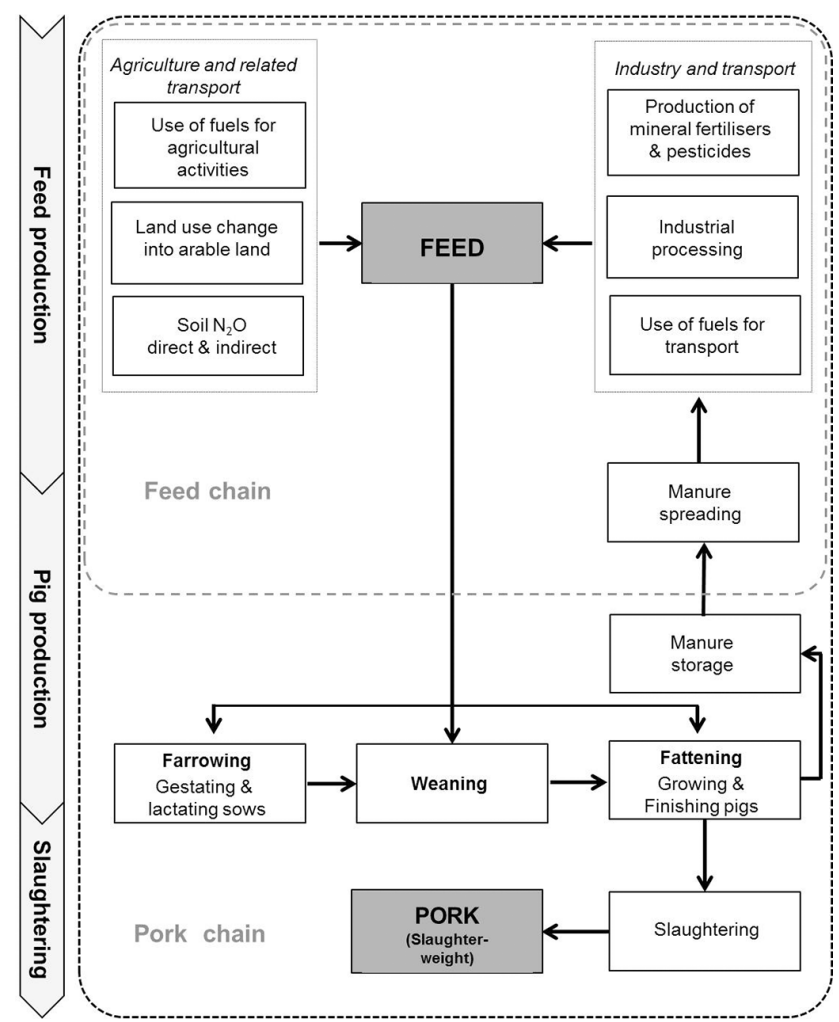

Figure 1. Pork supply chain within the system boundaries chosen. The feed chain within the dashed grey line is considered when results are expressed per kilogram of feed. The pork chain within the dotted black line is considered when the outcome is related to the production of pork.

application to pork production are described in Reckmann et al. (2012). Three different pig feed scenarios were modelled, each with a different partial substitution of soybean feed composition compared to that of ST (Table 1). All diets were formulated with respect to the currently accepted limits of maximum inclusion levels for different feed ingredients, as described below.

- Scenario LOW: this alternative scenario involved a combination of various feedstuffs, e.g. rapeseed meal, fava beans, and wheat distillers' dried grains with soluble (DDGS), which were identified in previous studies as having low environmental impacts (Meul et al., 2012; van der Werf et al., 2005).

- Scenario LEG: this scenario involved the maximum use of legumes in the diets, considering recommendations of the association for nutritional physiology (GfE, 2006). Legumes have high protein contents and a reduced need for $\mathrm{N}$ fertilisation due to the atmospheric $\mathrm{N}$ fixation of the crops (Lehuger et al., 2009).

- Scenario AA: in this scenario, synthetic amino acids were used intensively to reduce the crude-protein content of the diets. The reduced crude-protein content was 
Table 1. Ingredients of standard (ST) and alternative (LOW, LEG, AA) diets for sows and fattening pigs.

\begin{tabular}{|c|c|c|c|c|c|c|c|c|c|c|c|c|c|c|c|c|}
\hline \multirow[t]{2}{*}{ Ingredients (\%) } & \multicolumn{4}{|c|}{ Gestating sows } & \multicolumn{4}{|c|}{ Lactating sows } & \multicolumn{4}{|c|}{ Growing pigs } & \multicolumn{4}{|c|}{ Finishing pigs } \\
\hline & ST & LOW & LEG & AA & ST & LOW & LEG & $\mathrm{AA}$ & ST & LOW & LEG & AA & $\mathrm{ST}$ & LOW & LEG & AA \\
\hline Wheat & 26.0 & 26.0 & 26.0 & 26.0 & 40.0 & 40.0 & 40.0 & 40.0 & 40.0 & 39.9 & 38.4 & 48.5 & 36.0 & 40.1 & 33.1 & 46.0 \\
\hline Barley & 37.0 & 37.0 & 37.0 & 40.0 & 30.0 & 30.0 & 30.0 & 37.2 & 37.0 & 37.0 & 37.0 & 37.0 & 45.0 & 39.0 & 45.0 & 45.0 \\
\hline $\mathrm{SBM}^{\mathrm{a}}$ & 6.0 & 0 & 1.0 & 3.0 & 18.0 & 3.0 & 9.0 & 10.0 & 20.0 & 3.0 & 5.0 & 11.0 & 16.5 & 0 & 3.0 & 6.0 \\
\hline $\mathrm{RSM}^{\mathrm{b}}$ & 0 & 2.0 & 0 & 0 & 0 & 5.0 & 0 & 0 & 0 & 5.0 & 0 & 0 & 0 & 5.5 & 0 & 0 \\
\hline DDGS $^{\mathrm{c}}$ & 0 & 2.0 & 0 & 0 & 0 & 4.6 & 0 & 0 & 0 & 5.0 & 0 & 0 & 0 & 5.5 & 0 & 0 \\
\hline Fava beans & 0 & 2.0 & 5.0 & 0 & 0 & 5.0 & 14.0 & 0 & 0 & 5.0 & 15.0 & 0 & 0 & 5.5 & 15.0 & 0 \\
\hline Wheat bran & 17.0 & 17.0 & 17.0 & 17.0 & 5.5 & 4.6 & 0.4 & 5.5 & 0 & 0 & 0 & 0 & 0 & 0 & 0 & 0 \\
\hline Beet pulp & 10.0 & 10.0 & 10.0 & 10.0 & 2.0 & 2.0 & 2.0 & 2.0 & 0 & 0 & 0 & 0 & 0 & 0 & 0 & 0 \\
\hline $\mathrm{RSO}^{\mathrm{d}}$ & 1.0 & 1.0 & 1.0 & 1.0 & 1.5 & 3.0 & 1.5 & 2.0 & 0 & 1.5 & 1.0 & 0 & 0 & 1.5 & 1.0 & 0 \\
\hline Lysine & 0 & 0.05 & 0 & 0.05 & 0 & 0.25 & 0.05 & 0.20 & 0 & 0.35 & 0.25 & 0.3 & 0 & 0.35 & 0.20 & 0.35 \\
\hline Threonine & 0 & 0 & 0 & 0 & 0 & 0.10 & 0.05 & 0.05 & 0 & 0.15 & 0.15 & 0.15 & 0 & 0.10 & 0.10 & 0.15 \\
\hline Methionine & 0 & 0 & 0 & 0 & 0 & 0.05 & 0.05 & 0.05 & 0 & 0.05 & 0.15 & 0.10 & 0 & 0 & 0.10 & 0.05 \\
\hline
\end{tabular}

${ }^{a}$ SBM: soybean meal; ${ }^{b}$ RSM: rapeseed meal; ${ }^{c}$ DDGS: distillers' dried grains with solubles; ${ }^{\mathrm{d}}$ RSO: rapeseed oil.

expected to reduce the $\mathrm{N}$ excretion of pigs, thus influencing the results when assessing the whole pork supply chain.

Overall, 16 different diets were assessed and compared (each scenario - ST, LOW, LEG, and AA - for each animal category - GE, LA, GRO, and FI).

\section{Feed ingredients and compositions}

Feed ingredients of the different pig diets are listed in Table 1; chemical compositions are shown in Table S2 in the Supplement. All diets were formulated with regard to nutritional requirements recommended by the association for nutritional physiology (GfE, 2006). It was assumed that the performance of pigs was not influenced by the different diets since nutritional requirements were fully met. In addition, a diet for piglets $(8-30 \mathrm{~kg})$ was included in the overall assessment but was not varied in terms of soybean inputs. Previous analyses (Reckmann et al., 2013) showed that the piglet stage did not contribute considerably to the overall impacts of pork production; thus, it is not mentioned further.

For sow diets, energy content was fixed at $11.8-12.2 \mathrm{MJ}$ of metabolisable energy (ME) for gestation and 13.0-13.4 MJ $\mathrm{ME}$ for lactation. Lysine content for gestating sows was set at a minimum of $6 \mathrm{~g} \mathrm{~kg}^{-1}$ with an assumed ideal protein pattern of lys:met + cys:thr:try of 1:0.55:0.65:0.18, while for lactating sows lysine content was set at $9.5 \mathrm{~g} \mathrm{~kg}^{-1}$ with an assumed ideal amino acid pattern of 1:0.6:0.65:0.2. Digestible $\mathrm{P}$ content was $2.2 \mathrm{~g} \mathrm{~kg}^{-1}$ for gestating and $3.3 \mathrm{~g} \mathrm{~kg}^{-1}$ for lactating sows. The mineral vitamin mix used contained additional amino acids and 500 units of phytase. All alternative diets were supplemented with synthetic amino acids in order to meet amino acid requirements. Diets for growing and finishing pigs contained about $13 \mathrm{MJ}$ ME. Amino acid content was balanced according to an ideal amino acid pattern of 1:0.55:0.65:0.18. The minimum lysine content of the diets was $10.5 \mathrm{~g} \mathrm{~kg}^{-1}$ for growing and $9.0 \mathrm{~g} \mathrm{~kg}^{-1}$ for finishing pigs. Digestible phosphorus content was set to meet or ex- ceed $2.5 \mathrm{~g} \mathrm{~kg}^{-1}$ for growing and $2.1 \mathrm{~g} \mathrm{~kg}^{-1}$ for finisher pigs. All diets were supplemented with a mineral vitamin mix containing additional amino acids and 500 units of phytase per kilogram of diet. There are limited environmental data available for mineral feed and vitamins added. Since the amount of these additives is comparable in the different diets (2.5$3.0 \%$ ), we did not consider their environmental impacts. Additionally, all diets were formulated with respect to the currently accepted limits of maximum inclusion levels for different feed ingredients due to antinutritive factors (Meul et al., 2012; van der Werf et al., 2005) using a feed optimising software tool (Zifo WIN v1.5). Thus, maximum inclusion rates (Hoffmann and Steinhöfel, 2010) were set for rapeseed meal (5-10\%), DDGS (20\%), beet pulp (10\%), wheat bran $(20 \%)$, and fava beans (15-20\%). However, it has to be noted that these maximum inclusion rates are not fixed values.

\subsection{Life cycle assessment (LCA) methodology}

\subsubsection{Data inventory}

Figure 1 shows a schematic overview of the pork supply chain within the system boundaries chosen. The feed chain encompassed the production of pre-products (e.g. fertilisers and pesticides), the use of fuels for transport and agricultural activities, land use activities, and the processing into feedstuffs (kilogram of feed). The pork chain encompassed all processes within the feed chain, and, in addition, it included pig housing, manure management, and slaughtering. The final product was pork as slaughter weight. According to the PAS 2050 (British Standard Institution, 2008), production processes which play a minor role (e.g. chemicals and buildings) were excluded from the system. A data inventory for both systems is presented in the following. 


\section{Feed chain}

The data inventories of wheat, barley, and fava beans were based on the Ecoinvent database v2.1 (2009) but modified in terms of current crop yields and fertiliser use in Germany. Data for the rapeseed production originated from Schmidt (2007), whereas the processing was similar to that in Jungbluth et al. (2007). It was assumed that the soybeans (Ecoinvent, 2009) were produced in Brazil. The transformation of soybeans and rapeseed into meal is associated with the co-production of soybean oil and rapeseed oil. Due to the attributional LCA applied in the current study, an allocation was necessary (Nguyen et al., 2011; Reckmann et al., 2012), and economic allocation was applied in this study. In the case of soybeans, we used the economic allocation as described in Nguyen et al. (2011), resulting in allocation factors of $66.3 \%$ for soybean meal and $33.7 \%$ for soybean oil. Rapeseed was allocated according to Schmidt (2010), resulting in factors of $27 \%$ for rapeseed meal and $73 \%$ for rapeseed oil. 'With regard to the production of wheat bran, $73.9 \%$ of production was allocated to flour, $24.2 \%$ to bran and $1.9 \%$ to residues (Zygouras et al., 2005). Beet pulp was also economically allocated, resulting in factors of $91.7 \%$ for sugar, $4.5 \%$ for molasses and $3.8 \%$ for beet pulps (Jungbluth et al., 2007). Processing emissions were added, and the drying of sugar beet pulp caused $692 \mathrm{~g} \mathrm{CO}_{2}$-eq kg ${ }^{-1}$ beet pulp (Ecoinvent, 2009; Meul et al., 2012). Allocation factors of DDGS were gathered from Jungbluth et al. (2007). The production of amino acids is assumed to proceed as described in Mosnier et al. (2011), who include data due to fermentation and chemical synthesis of products. Since the content of the mineral composition in the feed did not differ between various scenarios of the pig group, it was not considered in the LCA and the comparison was considered the same across the groups.

Data regarding the processes to transform feed ingredients into feedstuffs were provided by a feed company in Germany. The manufacturing of $1 \mathrm{t}$ feed is connected with an energy use of $3.9 \mathrm{kWh}$, a heat (oil) use of $57.6 \mathrm{MJ}$, a water use of $0.02 \mathrm{~m}^{3}$, and the emission of $80 \mathrm{~g}$ particulates. Additional information is given in the Supplement.

\section{Pork chain}

Since feed production is part of the pork supply chain as indicated in Fig. 1, the data inventory of the pork chain started with the processes described above. It continued with the amount of feed needed to raise the pigs. It also included pig housing as well as the slaughtering of the animals. A detailed description of the assumptions for the LCA of pork is given in the Supplement, and basic essentials are described in the following. To represent the pig farm, we used a pig farm model as specified in Reckmann and Krieter (2014). We thereby focused on the gestating, farrowing, weaning (8$30 \mathrm{~kg}$ ), and finishing (30-120 kg) stages while using the most recent data available for northern Germany, mainly from the
Table 2. Main farm performance parameters of the average pig production in northern Germany in the marketing year 2011/2012.

\begin{tabular}{|c|c|c|c|}
\hline & Parameter & Value & Unit \\
\hline \multirow{6}{*}{$\begin{array}{l}0 \\
.0 \\
0 \\
0 \\
0 \\
0 \\
0 \\
0 \\
\frac{0}{0} \\
.00 \\
0\end{array}$} & Sows per farm & 270 & no. \\
\hline & Replacement rate & 45 & $\%$ \\
\hline & Live-born piglets per sow and year & 32.4 & no. \\
\hline & Weaned piglets per sow and year & 27.7 & no. \\
\hline & Litters per sow and year & 2.3 & no. \\
\hline & Piglet losses & 14.6 & $\%$ \\
\hline \multirow{2}{*}{$\frac{\infty}{\Xi}$} & Daily weight gain & 460 & $\mathrm{~g}$ \\
\hline & Piglet losses & 2.4 & $\%$ \\
\hline \multirow{7}{*}{ 品 } & Fattening pigs per farm & 1399 & no. \\
\hline & Final fattening weight & 120 & $\mathrm{~kg}$ \\
\hline & Carcass yield & 78.9 & $\%$ \\
\hline & Daily weight gain & 806 & $\mathrm{~g}$ \\
\hline & Feed conversion ratio 1 & 2.84 & $\mathrm{~kg}$ \\
\hline & Lean-meat content & 57.2 & $\%$ \\
\hline & Animal losses & 3.1 & $\%$ \\
\hline
\end{tabular}

marketing year 2011/2012 (SSB, 2012). The main performance parameters of average pig production are listed in Table 2, remaining the same throughout all analyses. Electricity, heat, and water were needed for the rearing of the pigs. The excreta of the animals were stored as slurry in the pit beneath the slats for around 1 month. After this period, manure was pumped to an external storage tank outside the stable, where it developed a natural crust. After 6 months of prescribed storage, the manure was ready for field application, thereby replacing synthetic fertilisers in the cultivation of crops. The average distance to the field was $10 \mathrm{~km}$, while the application of the manure consumed $21 \mathrm{MJ} \mathrm{t}^{-1}$ slurry exstorage (Dalgaard et al., 2001). The substitution of artificial fertiliser was regarded as a positive effect since it avoided fertiliser production using related resources (e.g. $0.4 \mathrm{MJ} \mathrm{kg}^{-1}$ fertiliser N; Dalgaard et al., 2001) and emissions. All impacts related to the non-application of synthetic fertilisers were deducted from the system. In contrast, the spreading of manure occurred along with emission of pollutants, which could be rated as a negative effect. Overall, the $\mathrm{N}$ in the pig manure substituted $75 \%$ of synthetic $\mathrm{N}$ fertiliser (Nguyen et al., 2011); the substitution rate of $P$ was $97 \%$ (Dalgaard et al., 2006). According to Sommer et al. (2008), the substitution rate of $\mathrm{K}$ in manure was $100 \%$. All environmental impacts related to manure management, including in-house storage, outside storage, and field application, were allocated to pork production. Details of the manure characteristic calculations can be found in Nguyen et al. (2011) and in Fig. S1 in the Supplement.

At a final live weight of $120 \mathrm{~kg}$, the animals were transported $350 \mathrm{~km}$ from the farm to the slaughterhouse (Dreier, 2012). The final product was pork as slaughter weight, whereas the slaughter weight of the finishing pigs averaged 
Table 3. Global warming potential (GWP), eutrophication potential (EP), acidification potential (AP), and land use (LU) of feed ingredients (per kilogram of ingredient). GWP originating from direct (dLUC) and total (total LUC) land use change is listed separately.

\begin{tabular}{l|rrrr|r|r}
\hline $\begin{array}{l}\text { Feed } \\
\text { ingredient }\end{array}$ & $\begin{array}{r}\mathrm{GWP} \\
\left(\mathrm{g} \mathrm{CO}_{2} \text {-eq }\right)\end{array}$ & $\begin{array}{r}\mathrm{EP} \\
\left(\mathrm{g} \mathrm{PO}_{4} \text {-eq }\right)\end{array}$ & $\begin{array}{r}\mathrm{AP} \\
\left(\mathrm{g} \mathrm{SO}_{2} \text {-eq }\right)\end{array}$ & $\begin{array}{r}\mathrm{LU} \\
\left(\mathrm{m}^{2} \mathrm{yr}^{-1}\right)\end{array}$ & $\begin{array}{r}\mathrm{GWP} \text { from } \\
\mathrm{dLUC} \\
\left(\mathrm{g} \mathrm{CO}_{2} \text {-eq }\right)\end{array}$ & $\begin{array}{r}\text { GWP from } \\
\text { total LUC } \\
\left(\mathrm{g} \mathrm{CO}_{2} \text {-eq }\right)\end{array}$ \\
\hline Wheat & 547 & 2.8 & 2.6 & 1.55 & 0 & 222 \\
Barley & 442 & 8.2 & 3.6 & 1.34 & 0 & 192 \\
Soybean meal & 480 & 1.6 & 1.2 & 1.76 & 520 & 252 \\
Rapeseed meal & 451 & 1.9 & 2.5 & 2.90 & 0 & 415 \\
Rapeseed oil & 2008 & 8.9 & 9.6 & 5.47 & 0 & 782 \\
DDGS & 914 & 0.3 & 2.0 & 0.03 & 0 & 5 \\
Fava beans & 989 & 6.4 & 3.0 & 2.91 & 0 & 416 \\
Beet pulp & 704 & 0.1 & 0.1 & 0.10 & 0 & 14 \\
Wheat bran & 782 & 6.4 & 6.4 & 1.30 & 0 & 186 \\
Lysine & 4940 & 10.1 & 14.9 & 0.20 & 0 & 29 \\
Threonine & 4940 & 10.1 & 14.9 & 0.20 & 0 & 29 \\
Methionine & 2890 & 2.0 & 7.4 & 0.01 & 0 & 1 \\
\hline
\end{tabular}

$95 \mathrm{~kg}$. The slaughtering process consumed heat, electricity, water, and energy for transportation and produced emissions to air and water. Primary data were supplied by a slaughterhouse, and the inventory data are presented in Table S2.

\subsubsection{System boundaries and impact categories}

Results given as two different functional units: kilogram of feed and kilogram of pork. An LCA for each of the scenarios was performed, considering a simultaneous change in farrowing and fattening diets. Only diets of the same scenario were included in the different stages; no combination of different scenarios across diets took place.

The outcomes of the LCA were expressed in impact categories of global warming potential (GWP), eutrophication potential (EP), acidification potential (AP), and land use (LU). Results of the first three categories were calculated using the CML 2 Baseline method v2.05 (CML, 2009), whereas the IMPACT 2002+ method v2.10 (Jolliet et al., 2003) was used for the calculation of LU. Equivalence factors were defined according to the IPCC guidelines (IPCC, 2006), using a 100-year time horizon for the GWP. All calculations were performed in SimaPro 7.3.3 (Pré Consultants, 2009).

\section{Emissions related to land use change}

Direct LUC relates to the conversion of land directly attributed to the production of one or more feed ingredients (i.e. soybeans). In contrast, iLUC attributes conversion of land induced by changes in the production of or demand for feed ingredients (Schmidt et al., 2011). Since there is no consensus about the method to calculate LUC emissions (Flysjö, 2012; van Middelaar et al., 2013) and LUC emissions are non-recurrent in contrast to other emissions which recur annually (van Middelaar et al., 2013), LUC emissions were presented separately from other emissions.

\section{Taking direct LUC (dLUC) into account}

Since the EU demand for soybeans is responsible for tropical forest conversion and due to the methodology of dLUC, LUC emissions were related to the use of soybean products. As recommended in the "EU product environmental footprint (PEF) guide" (European Commission, 2013), dLUC emissions were allocated to feed for 20 years. Data from Jungbluth et al. (2007) were used stating that $3.2 \%$ of total soybeans in Brazil originated from tropical forest. Furthermore, $5.2 \%$ were converted from shrubland. Default values from the IPCC (2006) were used for carbon stocks in aboveand below-ground biomass, dead organic matter, and soil for tropical forest, shrubland, and cropland. This procedure resulted in $2081 \mathrm{~kg} \mathrm{CO}_{2}$-eq ha ${ }^{1}$ soybeans, being equivalent to $784 \mathrm{~kg} \mathrm{CO}_{2}$-eq t${ }^{-1}$ soybeans. These values were adapted from Meul et al. (2012). Considering the allocation factor of $66.3 \%$ for soybean meal, the emissions from dLUC resulted in $520 \mathrm{~kg} \mathrm{CO}_{2}$-eq t ${ }^{-1}$ soybean meal.

\section{Taking total LUC risk into account}

Due to the attributional LCA applied, total LUC risk (dLUC and iLUC) was calculated for each diet and each scenario based on historical and current deforestation rates (Audsley et al., 2009; Lange, 2011; Meul et al., 2012). The same value as proposed by Audsley et al. (2009) and Meul et al. (2012) was used, assuming a total LUC risk of $1430 \mathrm{~kg} \mathrm{CO}_{2}$-eq ha ${ }^{1}$ of agricultural land use associated with each diet. 
Table 4. Global warming (GWP), GWP including direct (GWP incl. dLUC) and total (LUC incl. total LUC) land use change, eutrophication (EP), acidification (AP), and land use (LU) for different pig diets (standard diet: ST; mix of low environmental impact ingredients: LOW; maximum use of legumes: LEG; and increased use of amino acids: AA) per kilogram of feed.

\begin{tabular}{|c|c|c|c|c|c|c|c|}
\hline \multicolumn{2}{|c|}{ Pig diets } & \multirow{2}{*}{$\begin{array}{l}\mathrm{GWP} \\
\left(\mathrm{g} \mathrm{CO}_{2} \text {-eq }\right) \\
467.3\end{array}$} & \multirow{2}{*}{$\begin{array}{l}\text { GWP incl. } \\
\text { dLUC } \\
\left(\mathrm{gCO}_{2} \text {-eq) }\right. \\
498.5\end{array}$} & \multirow{2}{*}{$\begin{array}{l}\text { GWP incl. } \\
\text { total LUC } \\
\left(\mathrm{g} \mathrm{CO}_{2} \text {-eq }\right) \\
641.9\end{array}$} & \multirow{2}{*}{$\begin{array}{l}\mathrm{EP} \\
\left(\mathrm{gPO}_{4} \text {-eq) }\right. \\
4.56\end{array}$} & \multirow{2}{*}{$\begin{array}{l}\mathrm{AP} \\
\left(\mathrm{g} \mathrm{SO}_{2} \text {-eq }\right) \\
2.93\end{array}$} & \multirow{2}{*}{$\begin{array}{l}\begin{array}{l}\mathrm{LU} \\
\left(\mathrm{m}^{2} \mathrm{yr}^{-1}\right)\end{array} \\
1.21\end{array}$} \\
\hline & ST & & & & & & \\
\hline 急㧛 & LOW & 486.3 & 486.3 & 660.8 & 4.64 & 3.00 & 1.22 \\
\hline 剀 & LEG & 488.3 & 493.5 & 669.9 & 4.79 & 2.30 & 1.27 \\
\hline & AA & 456.9 & 472.5 & 627.1 & 4.72 & 2.30 & 1.19 \\
\hline \multirow{4}{*}{ 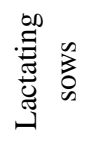 } & ST & 499.0 & 592.6 & 704.9 & 3.99 & 2.74 & 1.44 \\
\hline & LOW & 586.2 & 601.8 & 807.9 & 4.34 & 3.13 & 1.55 \\
\hline & LEG & 548.3 & 595.1 & 781.4 & 4.41 & 2.75 & 1.63 \\
\hline & AA & 512.1 & 564.1 & 715.2 & 4.44 & 2.98 & 1.42 \\
\hline \multirow{4}{*}{ 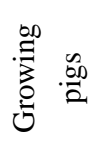 } & ST & 451.7 & 555.7 & 651.9 & 3.95 & 2.48 & 1.40 \\
\hline & LOW & 546.9 & 562.5 & 760.0 & 4.34 & 2.93 & 1.49 \\
\hline & LEG & 555.3 & 581.3 & 787.0 & 4.79 & 2.86 & 1.62 \\
\hline & AA & 480.2 & 537.4 & 679.0 & 4.10 & 2.67 & 1.39 \\
\hline \multirow{4}{*}{ 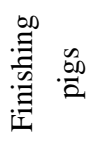 } & ST & 479.2 & 565.0 & 695.1 & 5.38 & 2.77 & 1.51 \\
\hline & LOW & 547.5 & 547.5 & 760.6 & 4.47 & 2.98 & 1.49 \\
\hline & LEG & 538.3 & 553.9 & 765.7 & 5.14 & 2.92 & 1.59 \\
\hline & AA & 471.4 & 502.6 & 665.9 & 4.50 & 2.80 & 1.36 \\
\hline
\end{tabular}

\section{Results}

\subsection{LCA of feed chain}

\subsubsection{LCA of different feed ingredients}

LCA results of different feed ingredients with respect to the impact categories assessed are listed in Table 3. The GWP ranged from 442 (barley) to $2008 \mathrm{~g}$ (rapeseed oil) $\mathrm{CO}_{2}$-eq kg ${ }^{-1}$ ingredient. The amino acids lysine, threonine, and methionine showed higher values. The EP ranged from 0.1 (beet pulp) to 8.9 (rapeseed oil) $\mathrm{g} \mathrm{PO}_{4}-\mathrm{eq} \mathrm{kg}^{-1}$ ingredient, whereas the AP showed comparable values. The highest land use was caused by the production of $1 \mathrm{~kg}$ rapeseed oil $\left(5.47 \mathrm{~m}^{2} \mathrm{yr}^{-1}\right)$. The inclusion of dLUC emissions would only affect the GWP of soybean meal. By contrast, the GWP related to total LUC risk varied from 1 (for methionine) to 782 (for rapeseed oil) $\mathrm{g} \mathrm{CO}_{2}$-eq kg ${ }^{-1}$ ingredient.

\subsubsection{LCA of different scenarios using varying pig diets}

Table 4 summarises the results of all diets assessed. The standard diet for gestating sows showed the least values for all impact categories assessed. It resulted in a GWP of $467.3 \mathrm{~g} \mathrm{CO}_{2}$-eq kg-1 feed. Considering LUC emissions increased the GWP by $6.7 \%$ (dLUC) and $37.4 \%$ (total LUC risk), respectively. The GWP increased by up to $4.5 \%$ (LEG), when alternative diets were compared to ST (see Table 4). The estimation of EP resulted in values of 4.56 (ST) to 4.79 (LEG) $\mathrm{g} \mathrm{PO}_{4}$-eq kg ${ }^{-1}$ feed for alternative diets. The AP of LEG and AA diets was lower compared to ST, whereas the value increased slightly by $2.4 \%$ for the LOW diet. Of the alternative diets, AA used the least land $\left(1.19 \mathrm{~m}^{2} \mathrm{yr}^{-1}\right)$.

The results of diets for lactating sows illustrated that the inclusion of dLUC emissions increased the GWP by $2.6 \%$ (LOW) to $15.8 \%$ (ST). Accounting for total LUC risk resulted in a $37.8 \%$ (LOW) to $42.5 \%$ (LEG) increased GWP. The resulting EP was $3.99 \mathrm{~g} \mathrm{PO}_{4}$-eq kg${ }^{-1}$ ST feed (Table 4), whereas it increased only slightly (8.8-11.3\%) when assessing alternative diets. See Table 4 for AP and LU.

When dLUC emissions were added to the GWP results of the diets of growing pigs, values increased by $2.8 \%$ (LOW) to $18.7 \%$ (ST). The EP of diets for growing pigs ranged from 3.95 (ST) to 4.79 (LEG) $\mathrm{g} \mathrm{PO}_{4}$-eq kg ${ }^{-1}$ feed, whereas the AP showed values of 2.48 (ST) to 2.93 (LOW) $\mathrm{g} \mathrm{SO}_{2}$-eq kg-1 feed. The LU varied within a small range of 1.39 (AA) and 1.62 (LEG) $\mathrm{m}^{2} \mathrm{yr}^{-1} \mathrm{~kg}^{-1}$ feed.

The assessment of diets for finishing pigs resulted in a GWP of $479.2 \mathrm{~g} \mathrm{CO}_{2}$-eq kg${ }^{-1}$ standard diet (Table 4). When dLUC emissions were included, values increased by $15.2 \%$ (ST), $0 \%$ (LOW), $2.8 \%$ (LEG), and $6.2 \%$ (AA). By contrast, the resulting increase in total LUC risk ranged from $38.9 \%$ (LOW) to $45.1 \%$ (ST). The least impactful finishing diet in terms of EP was LOW (4.47 $\mathrm{g} \mathrm{PO}_{4}$-eq kg${ }^{-1}$ feed). The AP ranged from 2.77 (ST) to 2.98 (LOW) $\mathrm{g} \mathrm{SO}_{2}$-eq kg ${ }^{-1}$ feed. Most land was needed for the production of LEG $\left(1.59 \mathrm{~m}^{2} \mathrm{yr}^{-1} \mathrm{~kg}^{-1}\right.$ feed), whereas other diets decreased LU by up to $14.5 \%$ (AA). 


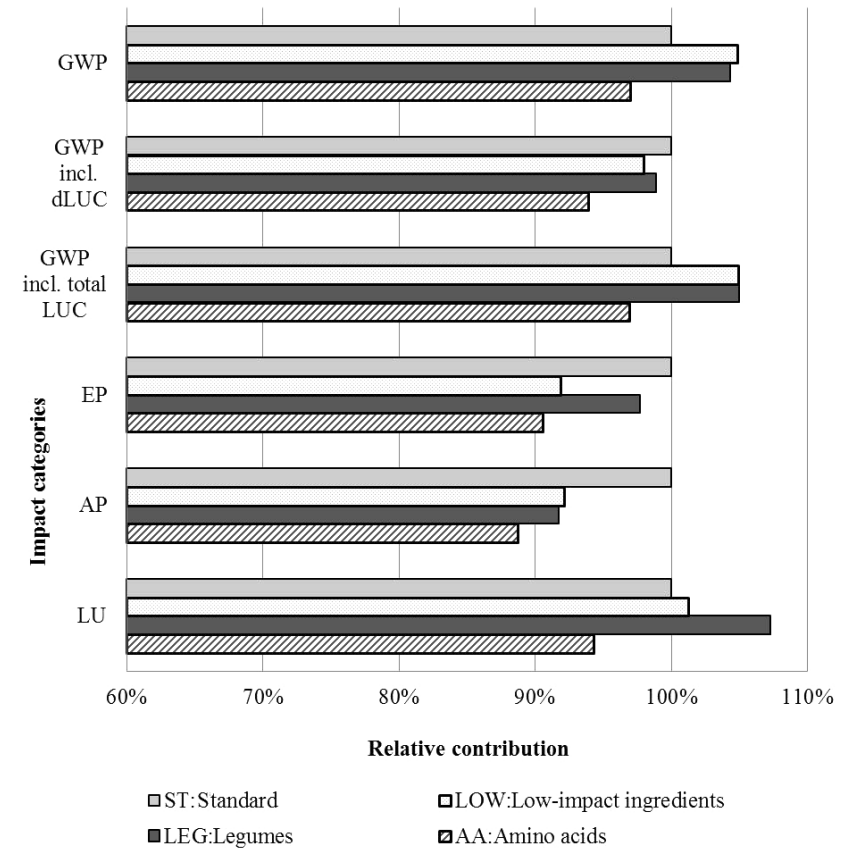

Figure 2. Contribution of different scenarios to global warming with emissions from direct (GWP incl. dLUC), total (GWP incl. total LUC), and no land use change (GWP), eutrophication (EP), acidification (AP), and land use (LU) in relation to the standard scenario. The assessment was performed per kilogram of pork considering the whole pork supply chain.

\subsection{LCA of pork chain}

The assessment of the pork supply chain resulted in a GWP of $3.01 \mathrm{~kg} \mathrm{CO}_{2}$-eq kg $\mathrm{g}^{-1}$ pork considering the standard diet. The inclusion of dLUC caused a GWP of $3.33 \mathrm{~kg} \mathrm{CO}_{2}$ eq $\mathrm{kg}^{-1}$ pork. Accounting for total LUC risk resulted in a GWP of $3.77 \mathrm{~kg} \mathrm{CO}_{2}$-eq kg${ }^{-1}$ pork. The EP was estimated at $28.4 \mathrm{~g} \mathrm{PO}_{4}$-eq, the AP reached $57.2 \mathrm{~g} \mathrm{SO}_{2}$-eq kg${ }^{-1}$ pork, and LU showed a value of $5.21 \mathrm{~m}^{2} \mathrm{yr}^{-1}$. Figure 2 illustrates that the LOW scenario resulted in highest GWP, directly followed by LEG. The outcome of AA was reduced by $3 \%$ compared to ST. When including dLUC emissions, the ST scenario appeared most impactful; the GWP of AA, in contrast, decreased by $6 \%$. The inclusion of total LUC risk highlighted LEG and LOW as having the highest GWP. The GWP of AA was reduced by $3 \%$ compared to ST, as demonstrated in Fig. 2. EP ranged from 25.8 (AA) to 27.8 (LEG) $\mathrm{g} \mathrm{PO}_{4}$ eq $\mathrm{kg}^{-1}$ pork. Results of the AP illustrated that ST had the highest values, whereas a maximum reduction was achieved via the feeding of AA diets $(-11 \%)$. In terms of LU, AA performed best, resulting in $4.92 \mathrm{~m}^{2}$ land used per year for the production of $1 \mathrm{~kg}$ pork. Using LEG diets to produce pork increased LU by $12 \%$. Overall, Fig. 2 highlights that the AA scenario performed best in all impact categories assessed. All impacts were reduced by 3 to $11 \%$ compared to the ST scenario.

\section{Discussion}

Since the agricultural expansion and the resulting LUC emissions are responsible for a considerable share of global greenhouse gas emissions, it is important to account for them in LCAs of food products. There is no consensus about the method to calculate LUC emissions (Flysjö et al., 2012; van Middelaar et al., 2013), and LUC emissions are nonrecurrent in contrast to other emissions which occur annually (van Middelaar et al., 2013). Thus, in this study LUC emissions were presented separately from other emissions and were considered in GWP. The comparative results showed GWP increased considerably when including dLUC of feed manufacturing in all feed alternative scenarios, except in LOW diets of gestating sows and finishing pigs, where it remained the same since no soybean meal was included. Despite the methodological limitations it was decided to use the same dLUC values as calculated by Meul et al. (2012) because this approach showed more comprehensive assumptions. In contrast, Flysjö et al. (2012) summarised several dLUC factors from different studies resulting in different values. These different factors have some influence on the results of this study, but the variation is not considerable enough to change the overall conclusion.

The main advantage of the dLUC method is that it addresses the major drivers of deforestation (Gerber et al., 2010; Leip et al., 2010), namely the cultivation of soybeans from South America. On the other hand, it does not consider land as a limited resource and that land use elsewhere can also affect LUC indirectly (Flysjö et al., 2012). Therefore, Schmidt et al. (2011) recommended the inclusion of total LUC risk (direct and indirect) in assessments, with the consideration that all occupation of land contributes to some LUC. When including emissions from total LUC risk, GWP results per kilogram of pork increased by 24.0 to $25.5 \%$ as compared to emissions without LUC. Similarly, Audsley et al. (2009) argue that total LUC risk should be included because all demand for agricultural land influences global markets and thereby contributes to LUC. Thus, it is important to consider LUC in GWP studies of food and feed production (van Middelaar et al., 2013).

As observed from the scenario analyses, the level of soybean meal replacement varied among the different diets and scenarios. For example, the replacement of soybean meal in GE ranged from $50 \%$ for AA to $100 \%$ for LOW as compared to ST. In comparison, the reduction level was lower in LA diets, while in GRO diets it was up to $75 \%$ for LOW and LEG scenarios. Similarly, soybean meal could be replaced completely in some FI diets. These values indicate that soybean replacement in AA diets was the least, whereas the LOW diet representing relatively lower impacting ingredients resulted in an almost $100 \%$ replacement.

This is similar to the results in Meul et al. (2012), who reached a higher level of reduction in soybean products in fattening diets, although the complete replacement of soy- 
beans was not considered in all their scenarios. On the other hand, discussions with various feed experts indicate that the amino acid composition of soybean products remains a limiting factor in the replacement.

Most of the LCA outcomes of feed ingredients in this study are in line with recent studies in the literature (Flysjö et al., 2012; Hörtenhuber et al., 2011; Meul et al., 2012; van der Werf et al., 2005). Nevertheless, results of some feed ingredients differ from those of other studies. For example, GWP and LU of DDGS did not comply with previous studies (Meul et al., 2012; Hörtenhuber et al., 2011), where $38.5 \%$ higher and $7.4 \%$ lower variations were observed, respectively. Additionally, the GWP in the present study increased more than 2-fold compared to the results of Hörtenhuber et al. (2011). On the other hand, the GWP impacts of beet pulp presented in this study were lower $(-16.8 \%)$ as compared to those from Meul et al. (2012). These differences might be due to varying energy use, differences in processing techniques, crop yields, or fertiliser use. Potential variation might be dependent on the databases used; feed ingredients presented in this study were analysed based on Ecoinvent database (2009). Uncertainties in the results were dealt with by using values from the literature, to see if errors in the ingredients could potentially affect the final ranking of the various scenarios. However, the use of literature values did not affect our conclusion for beet pulp because the content within pig groups remained the same over the various scenarios. By contrast, the inclusion of literature values in the cases of DDGS and fava beans slightly affected the results of the LOW and LEG diet scenarios. However, the overall conclusion remained the same because ST and AA scenarios were not affected due to the absence of DDGS and fava beans in the respective diets.

Assessments of the AA scenario by reducing crude-protein content had been expected to influence the $\mathrm{N}$ excreted by pigs (Portejoie et al., 2004). As expected, the different diets have resulted in a reduction in protein content value of $7.9 \%$ in GE, $15.4 \%$ in LA, $15.0 \%$ in GRO, and $19.4 \%$ in FI diets. The main parameters of the pork supply chain influenced by this change were $\mathrm{N}$ content of manure, emission from manure and replaced fertiliser use. It is assumed that pig performance was not affected. Thus, the $\mathrm{N}$ content of manure could be reduced by $14.7 \%$ as compared to ST, which in turn, affected the emissions of $\mathrm{CH}_{4}$, direct $\mathrm{N}_{2} \mathrm{O}$, and $\mathrm{NH}_{3}$ from pig production in a similar manner. Consequently, results of the various scenarios were influenced by these interactions.

Overall, the AA scenario was identified as having the least impacts in all categories assessed. However, it was assumed that the inclusion of synthetic amino acids in pig diets does not have any side effects. Hitherto, studies dealing with an LCA of alternative pig diets have set the system boundary at the gate of the feed company, thereby choosing feed as a functional unit (Meul et al., 2012; van der Werf et al., 2005; van Middelaar et al., 2013). This study is unique in that it presents, for the first time, an assessment of alternative pig diets per kilogram of pork. In this study, the whole pork supply chain was included by using an actual pig farm model (Reckmann and Krieter, 2014; see also the Supplement) to account for downstream processes which are influenced by different diet compositions, e.g. $\mathrm{N}$ excretion of pigs. The results indicated that replacement of soybeans with synthetic amino acids resulted in relatively better environmental performance. Hence, it is recommended that AA-replaced diets be used in pork production, but their applicability within an actual farm situation should be verified to avoid any possible side effects of using synthetic amino acids. Therefore, further research is required to determine the effects of using synthetic amino acids in the diets of pig when replacing soybeans in order to reduce the environmental impact of pork production.

\section{Conclusions}

The LCA of alternative diets in pig housing showed that the scenario with an increased use of amino acids performed best in terms of all the impact categories assessed when analysing the whole pork supply chain. This may be due to the reduction in crude-protein content of the diets that consequently lowered $\mathrm{N}$ and $\mathrm{CH}_{4}$ excretion of pigs. Thus, when considering the whole pork supply chain, it can be recommended to partly substitute soybean products in pig diets with amino acids to minimise the environmental impacts of pig feed.

\section{The Supplement related to this article is available online at doi:10.5194/aab-2-27-2016-supplement.}

Acknowledgements. The authors gratefully acknowledge the financial support of the ZDS e.V. and the Landwirtschaftliche Rentenbank. The paper greatly benefited from comments by Helmut Claus.

Edited by: K. Wimmers

Reviewed by: two anonymous referees

\section{References}

Audsley, E., Brander, M., Chatterton, J., Murphy-Bokern, D., Webster, C., and Williams, A. P: How low can we go? An assessment of greenhouse gas emissions from the UK food system and the scope to reduce them by 2050, WWF, UK, 2009.

Basset-Mens, C. and van der Werf, H. M. G.: Scenario-based environmental assessment of farming systems: the case of pig production in France, Agr. Ecosyst. Environ., 105, 127-144, 2005.

British Standard Institution: Guide to PAS 2050, How to assess the carbon footprint of goods and services, in: BSI, London, UK, 2008. 
Cederberg, C., Wivstad, M., Bergkvist, P., Mattsson, B., and Ivarsson, K.: Environmental assessment of plant protection strategies using scenarios for pig feed production, AMBIO, 34, 408-413, 2005.

CML: CML 2 Baseline 2000, Centre for Environmental Studies (CML), University Leiden, Leiden, the Netherlands, 2009.

Dalgaard, T., Halberg, N., and Porter, J. R.: A model for fossil energy use in Danish agriculture used to compare organic and conventional farming, Agr. Ecosyst. Environ. 87, 51-65, 2001.

Dalgaard, R., Halberg, N., Kristensen, I. S., and Larsen, I.: Modelling representative and coherent Danish farm types based on farm accountancy data for use in environmental assessments, Agr. Ecosyst. Environ. 117, 223-237, 2006.

Dalgaard, R., Halberg, N., and Hermansen, J. E.: Danish pork production - An environmental assessment, DJF Animal Science, 82, 34 pp., 2007.

de Boer, I. J. M., Cederberg, C., Eady, S., Gollnow, S., Kristensen, T., Macleod, M., Meul, M., Nemecek, T., Phong, L. T., Thoma, G., van der Werf, H. M. G., Williams, A. G., and ZonderlandThomassen, M. A.: Greenhouse gas mitigation in animal production: towards an integrated life cycle sustainability assessment, Current Opinion in Environmental Sustainability, 3, 423-431, 2011.

Dreier, C.: Untersuchung zu den Schlachtschweinetransporten aus dem Raum Norddeutschland in den Jahren 2005 bis 2011, Institute of Animal Breeding and Husbandry, Chritian-Albrechts University Kiel, Kiel, Germany, 2012.

Ecoinvent: Ecoinvent Data v 2.1, July 2009, Swiss Centre for Life Cycle Inventories, Dübendorf, Switzerland, 2009.

Eriksson, I., Elmquist, H., Stern, S., and Nybrant, T.: Environmental Systems Analysis of Pig Production - The Impact of Feed Choice (12 pp.), Int. J. Life Cycle Ass., 10, 143-154, 2005.

European Commission: Annex II : Product Environmental Footprint (PEF) Guide, COMMISSION RECOMMENDATION on the use of common methods to measure and communicate the life cycle environmental performance of products and organisations, European Commission, Brussels, Belgium, 2013.

Flysjö, A.: Greenhouse gas emissions in milk and dairy product chains - improving the carbon footprint of dairy products, Department of Agroecology, Aarhus University, Tjele, Denmark, 2012.

Flysjö, A., Cederberg, C., Henriksson, M., and Ledgard, S.: The interaction between milk and beef production and emissions from land use change - critical considerations in life cycle assessment and carbon footprint studies of milk, J. Clean. Prod., 28, 134142, 2012.

Foley, J. A., Ramankutty, N., Brauman, K. A., Cassidy, E. S., Gerber, J. S., Johnston, M., Mueller, N. D., O/'Connell, C., Ray, D. K., West, P. C., Balzer, C., Bennett, E. M., Carpenter, S. R., Hill, J., Monfreda, C., Polasky, S., Rockstrom, J., Sheehan, J., Siebert, S., Tilman, D., and Zaks, D. P. M.: Solutions for a cultivated planet, Nature, 478, 337-342, 2011.

Gerber, P., Vellinga, T., Opio, C., Henderson, B., and Steinfeld, H.: Greenhouse Gas Emissions from the Dariy Sector, A Life Cycle Assessment. FAO, Food and Agriculture Organization of the United Nations, Rome, Italy, 2010.

GfE: Empfehlungen zur Energie- und Nährstoffversorgung bei Schweinen, DLG-Verlag, Frankfurt am Main, Germany, 2006.
Hoffmann, M. and Steinhöfel, O.: Futtermittelspezifische Restriktionen, 5. Auflage, Deutscher Landwirtschaftsverlag, Munich, Germany, 2010.

Hörtenhuber, S. J., Lindenthal, T., and Zollitsch, W.: Reduction of greenhouse gas emissions from feed supply chains by utilizing regionally produced protein sources: the case of Austrian dairy production, J. Sci. Food. Agr., 91, 1118-1127, 2011.

IPCC: Guidelines for National Greenhouse Gas Inventories, IGES, Hayama, Japan, 2006.

Jolliet, O., Margni, M., Charles, R., Humbert, S., Payet, J., Rebitzer, G., and Rosenbaum, R.: IMPACT 2002+: A New Life Cycle Impact Assessment Methodology, Int. J. Life Cycle Ass., 8, 324-330, 2003.

Jungbluth, N., Chudacoff, M., Dauriat, A., Dinkel, F., Doka, G., Faist Emmenegger, M., Gnansounou, E., Kljun, N., Schleiss, K., Spielmann, M., Stettler, C., and Sutter, J.: Life cycle inventories of bioenergy, Ecoinvent report no.17. Swiss Centre for the Life Cycle Inventories, Dübendorf, Switzerland, 2007.

Lange, M.: The GHG balance of biofuels taking into account land use change, Energ. Policy, 39, 2373-2385, 2011.

Lehuger, S., Gabrielle, B. T., and Gagnaire, N.: Environmental impact of the substitution of imported soybean meal with locallyproduced rapeseed meal in dairy cow feed, J. Clean. Prod., 17, 616-624, 2009.

Leip, A., Weiss, F., Wassenaar, T., Perez, I., Fellmann, T., Loudjani, P., Tubiello, F., Grandgirard, D., Monni, S., and Biala, K.: Evaluation of the livestock sector's contribution to the EU greenhouse gas emissions (GGELS) - final report, European Commission, Joint Research Centre, Ispra, Italy, 2010.

Meul, M., Ginneberge, C., Van Middelaar, C. E., de Boer, I. J. M., Fremaut, D., and Haesaert, G.: Carbon footprint of five pig diets using three land use change accounting methods, Livest. Sci., 149, 215-223, 2012.

Mosnier, E., van der Werf, H. M. G., Boissy, J., Dourmad, and J. Y.: Evaluation of the environmental implications of the incorporation of feed-use amino acids in the manufacturing of pig and broiler feeds using Life Cycle Assessment, Animal, 5, 1972 1983, 2011.

Nemecek, T., von Richthofen, J.-S., Dubois, G. T., Casta, P., Charles, R. L., and Pahl, H.: Environmental impacts of introducing grain legumes into European crop rotations, Eur. J. Agron., 28, 380-393, 2008.

Nguyen, T. L. T., Hermansen, J. E., and Mogensen, L.: Environmental assessment of Danish pork, Aarhus University, Aarhus, Denmark, 2011.

Peters, G. P., Marland, G., Le Quere, C., Boden, T., Canadell, J. G., and Raupach, M. R.: Rapid growth in $\mathrm{CO} 2$ emissions after the 2008-2009 global financial crisis, Nature Clim. Change 2, 2-4, 2012.

Portejoie, S., Dourmad, J. Y., and Martinez, J.: Effect of lowering dietary crude protein on nitrogen excretion, manure composition and ammonia emission from fattening pigs, Livest. Prod. Sci., 91, 45-55, 2004.

Pré Consultants, B.: Sima Pro, the Netherlands, 2009.

Reckmann, K. and Krieter, J.: Environmental impacts of the pork supply chain with regard to farm performances, J. Agr. Sci., 153, 411-421, doi:10.1017/S0021859614000501, 2014. 
Reckmann, K., Traulsen, I., and Krieter, J. Environmental Impact Assessment - methodology with special emphasis on European pork production, J. Environ. Manage., 107, 102-109, 2012.

Reckmann, K., Traulsen, I., and Krieter, J.: Life Cycle Assessment of pork production: a data inventory for the case of Germany, Livest. Sci. 157, 586-596, 2013.

Schmidt, J.: Life cycle assessment (LCA) of rapeseed oil and palm oil, Department of Development and Planning. Aalborg University, Aalborg, Denmark, 2007.

Schmidt, J.: Comparative life cycle assessment of rapeseed oil and palm oil, Int. J. Life Cycle Ass., 15, 183-197, 2010.

Schmidt, J., Reinhard, J., and Weidema, B. P.: Modelling of indirect land use change in LCA. 2.-0 consultants, Aalborg, Denmark, 2011.

Sommer, S. G., Maahn, M., Poulsen, H. D., Hjorth, M., and Sehested, J.: Interactions between phosphorus feeding strategies for pigs and dairy cows and separation efficiency of slurry, Environ. Technol., 29, 75-80, 2008.

SSB: Schweinereport 2012, Schweinespezialberatung SchleswigHolstein e.V. und Landwirtschaftskammer Schleswig-Holstein, 2012. van der Werf, H. M. G., Petit, J., and Sanders, J.: The environmental impacts of the production of concentrated feed: the case of pig feed in Bretagne, Agr. Syst., 83, 153-177, 2005.

van Middelaar, C. E., Cederberg, C., Vellinga, T. V., Werf, H. M. G., and Boer, I. J. M.: Exploring variability in methods and data sensitivity in carbon footprints of feed ingredients, Int. J. Life Cycle Ass., 18, 768-782, 2013.

Weightman, R. M., Cottrill, B. R., Wiltshire, J. J. J., Kindred, D. R., and Sylvester-Bradley, R.: Opportunities for avoidance of landuse change through substitution of soya bean meal and cereals in European livestock diets with bioethanol coproducts, Global Change Biology Bioenegery, 3, 158-170, 2011.

Zygouras, G., Kornaros, M., and Angelopoulos, K.: Life Cycle Assessment (LCA) as a tool for assessing the environmental performance of flour production in Greece, 9th International Conference on environmental Science and Technology, 1-3 September 2005, Rhodes Island, Greece, 2005. 